\title{
Geoecological Zonation of Revegetation Enhances Biodiversity at Historic Mine Sites, Southern New Zealand
}

\author{
Dave Craw * and Cathy Rufaut
}

Citation: Craw, D.; Rufaut, C. Geoecological Zonation of Revegetation Enhances Biodiversity at Historic Mine Sites, Southern New Zealand. Minerals 2021, 11, 181. https://doi.org/10.3390/min11020181

Academic Editors: Benoit Plante, Thomas Pabst and David Wilson Received: 5 January 2021

Accepted: 6 February 2021

Published: 9 February 2021

Publisher's Note: MDPI stays neutral with regard to jurisdictional claims in published maps and institutional affiliations.

Copyright: (c) 2021 by the authors. Licensee MDPI, Basel, Switzerland. This article is an open access article distributed under the terms and conditions of the Creative Commons Attribution (CC BY) license (https:// creativecommons.org/licenses/by/ $4.0 /)$.
Geology Department, University of Otago, PO Box 56, Dunedin 9054, New Zealand; cathy.rufaut@otago.ac.nz * Correspondence: dave.craw@otago.ac.nz

\begin{abstract}
Rocks exposed by mining can form physically, mineralogically, and geochemically diverse surface substrates. Engineered mine rehabilitation typically involves covering these rocks with a uniform layer of soil and vegetation. An alternative approach is to encourage the establishment of plant species that are tolerant of challenging geochemical settings. The zonation of geochemical parameters can therefore lead to geoecological zonation and enhanced biodiversity. Abandoned gold mines in southern New Zealand have developed such geoecological zonations that resulted from establishment of salt-tolerant ecosystems on substrates with evaporative $\mathrm{NaCl}$. A salinity threshold equivalent to substrate electrical conductivity of $1000 \mu \mathrm{S}$ separates this ecosystem from less salt-tolerant plant ecosystems. Acid mine drainage from pyrite-bearing waste rocks at an abandoned coal mine has caused variations in surface $\mathrm{pH}$ between 1 and 7 . The resultant substrate $\mathrm{pH}$ gradients have led to differential plant colonisation and the establishment of distinctive ecological zones. Substrate $\mathrm{pH}<3$ remained bare ground, whereas $\mathrm{pH} 3-4$ substrates host two acid-tolerant shrubs. These shrubs are joined by a tree species between $\mathrm{pH} 4$ and 5. At higher $\mathrm{pH}$, all local species can become established. The geoecological zonation, and the intervening geochemical thresholds, in these examples involve New Zealand native plant species. However, the principle of enhancing biodiversity by the selection or encouragement of plant species tolerant of diverse geochemical conditions on exposed mine rocks is applicable for site rehabilitation anywhere in the world.
\end{abstract}

Keywords: gold; coal; salinity; acidity; threshold; revegetation; biodiversity

\section{Introduction}

Mine sites expose bare rocks to the surface, commonly with widely ranging physical and geochemical characteristics, and further geochemical variations can develop after the rocks are exposed to weathering [1-6]. Revegetation of these rock surfaces during mine rehabilitation can be problematic because some substrates are resistant to plant establishment [1-3,7]. In modern mines, this problem is typically overcome by a range of engineered solutions that depend on the specific features of the site and the specific legal and social demands [8-10]. One of the most common approaches is to spread a layer of topsoil that was previously stockpiled, along with natural and/or artificial amendments, and vegetation is established in that topsoil (Figure 1a). Additional layer(s) beneath the topsoil may also be added, for example as a cover to limit the incursion of water into acid-generating rocks $[2,3,6]$. The end result of these processes is generally a uniform rehabilitated landscape, but with limited biodiversity (Figure 1a) [11].

Biodiversity at rehabilitated mine sites could be enhanced by using a variety of approaches on different portions of a mine site, to avoid the uniformity of many engineered solutions. In particular, since many engineered solutions have limited success in the long term, the encouragement of more natural processes may be more successful $[9,10]$. At some sites, it may be possible to take advantage of some of the physical and geochemical variations inherent in the rocks exposed at the surface, encouraging colonisation by plant communities that are adapted to distinctive geochemical environments [8,9,11-13]. From 
this approach, different geoecological zones could be established, providing more ecological diversity while still covering the disturbed land [14-16]. Abandoned, historic mine sites are microcosms in which to study this type of reconstruction of diverse ecosystems via primary succession processes $[8,13,14]$. Such sites provide platforms to investigate the geoecological processes involved with vegetation establishment directly into a range of substrates with little or no topsoil under a range of climatic regimes $[3,13,17,18]$.

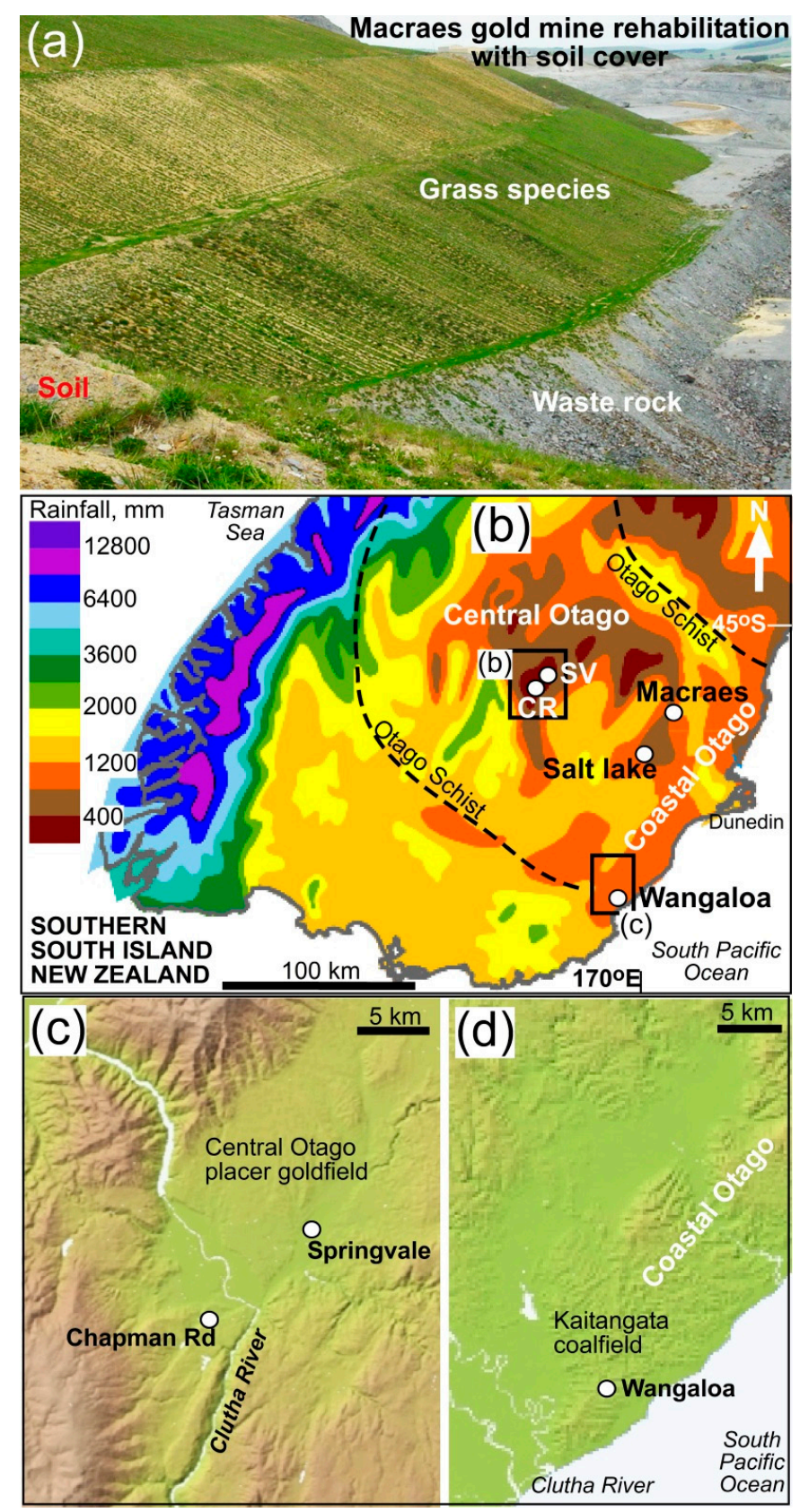

Figure 1. Regional setting for the mine sites outlined in this study. (a) Typical rehabilitation of schist debris at the modern Macraes orogenic gold mine (location in $\mathbf{b}$ ), leading to uniform vegetation and landscape. (b) Annual rainfall map of the southern South Island of New Zealand [19], showing the extreme rainfall gradients that lead to rain shadow effects to the east of the mountains on the western side of the island. Boundaries are indicated for the Otago Schist that forms the basement rocks and source for sediments at the sites studied. (c) Digital terrain model showing the topographic contexts for the historic Chapman Road and Springvale Placer gold mines. (d) Digital terrain model showing the topographic context for the historic Wangaloa coal mine. 
In this study, we document examples of the revegetation of physically and geochemically challenging substrates involving high salinity or high acidity at historic mine sites in southern New Zealand (Figure $1 \mathrm{~b}-\mathrm{d}$ ). These substrate variations have given rise to a range of geoecological zones with distinctive plant communities that effectively stabilise the surfaces for environmental purposes but also provide enhanced biodiversity that is seen as important by local people and government agencies. These geoecological zones are bounded by thresholds that are defined by mineralogical, geochemical, and geological features of the underlying substrates, in conjunction with the topography and climate (Figure $1 \mathrm{~b}-\mathrm{d}$ ). We quantify these thresholds and the underlying mineralogical and geochemical processes that control them. Our observations and conclusions have potential applicability for the rehabilitation of mine sites and other disturbed land elsewhere in the world, where similar geoecological zonation can be promoted as a management tool. While the plant species and associated ecosystems would likely be different in other geographic settings, the approach could be the same: taking advantage of exposed geological diversity rather than burying it beneath imported topsoil. The sites we describe are small (hectare scale), but even if only a small proportion of a site is rehabilitated in this way, local biodiversity could be positively enhanced $[8-10,12]$.

\section{General Setting}

\subsection{Underlying Geology}

Much of the southern South Island is underlain by the regionally extensive Otago Schist belt (Figure 1b), which is a greenschist facies metasedimentary terrane. The rocks are recrystallised lithic turbidite metagreywackes with pervasive foliation, and have uniform mineralogy dominated by quartz, albite, muscovite and chlorite, with subordinate calcite and pyrite. The basement is locally overlain by erosional remnants of a veneer of Cretaceous-Cenozoic sedimentary rocks that were derived from the basement schist. The nonmarine sedimentary rocks that immediately overlie the basement, and which are directly relevant to this study, consist of quartz pebble conglomerates (locally with placer gold), sandstones, siltstones and mudstones with interlayered lignite seams [20,21].

Groundwater-driven alteration near the unconformity between these nonmarine sediments and the basement has caused extensive clay alteration of the schist, principally to kaolinite, in the upper $20 \mathrm{~m}$ [22]. Clay alteration was typically accompanied by oxidation of schist in the upper $100 \mathrm{~m}$, and this oxidation has been accentuated by subsequent subaerial weathering (Figure 2a; Chamberlain et al. 1999 [22]). In addition, the groundwater-driven alteration has caused some quartz cementation of overlying quartz pebble conglomerates to form silcretes, clay cementation of associated siltstones and mudstones, and localised cementation by authigenic pyrite [22,23].

The whole region is currently subject to slow tectonic uplift $(<1 \mathrm{~mm} /$ year), with development of broad ranges of hills and mountains, with intervening tectonic basins (Figure 1c,d) [21]. Erosion during this Pliocene-Holocene uplift has shed lithic sediments, predominantly gravels and associated colluvium, from the slopes of rising hillsides on to the margins of the adjacent basins. Pleistocene wind-blown silt (loess) was derived by the glaciation of schist basement mountains and forms a 1-4 m thick cap on many parts of the landscape, and is also locally interlayered with the Pliocene-Holocene lithic sediments [21]. 

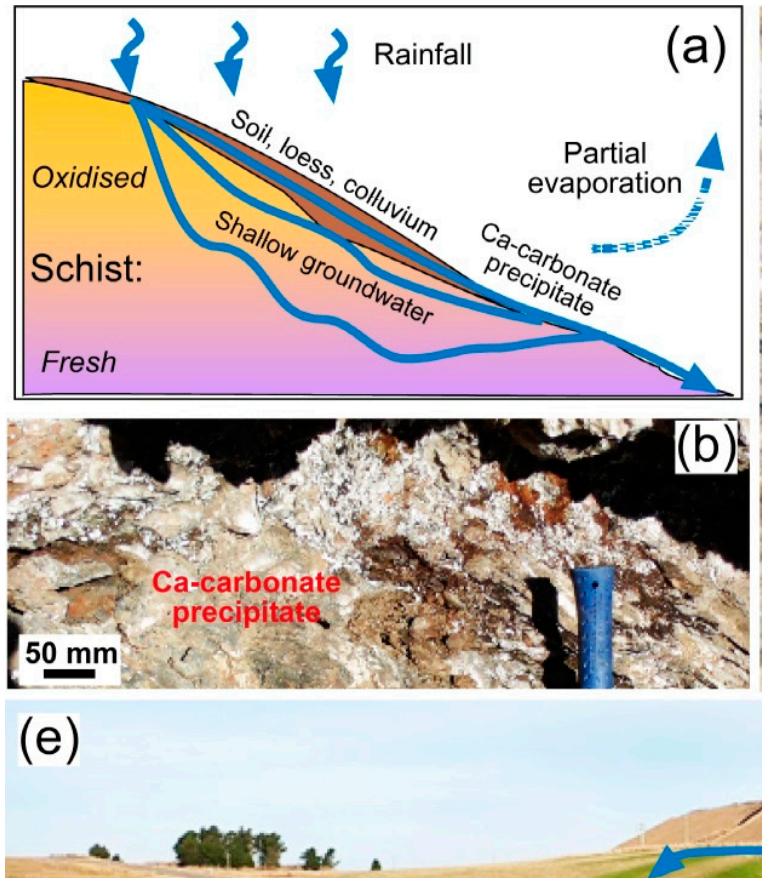

Grass with no irrigation

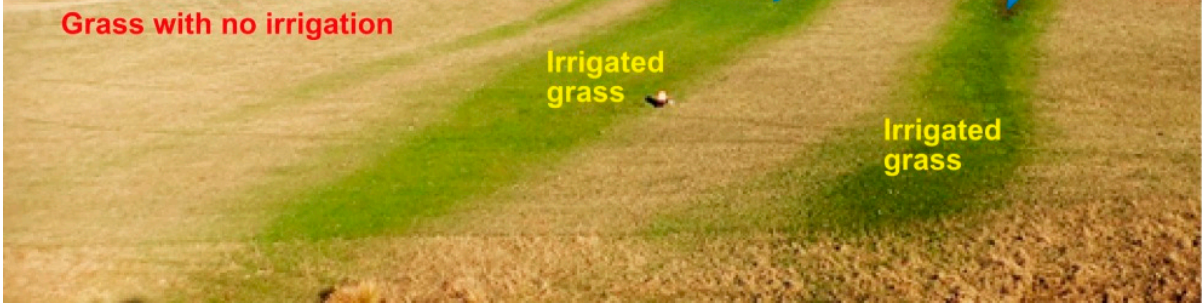

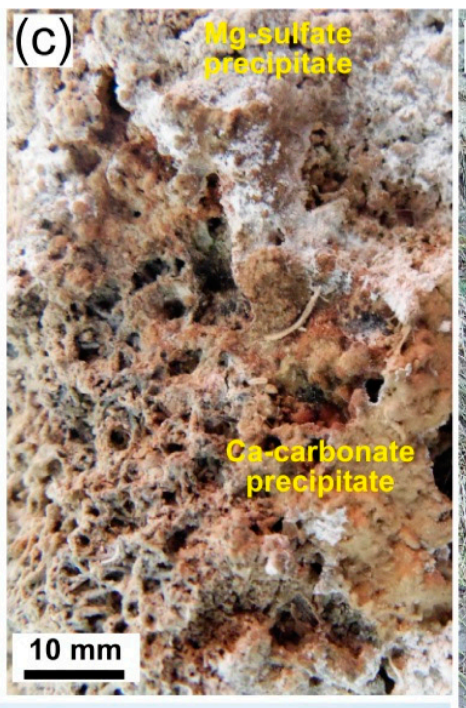

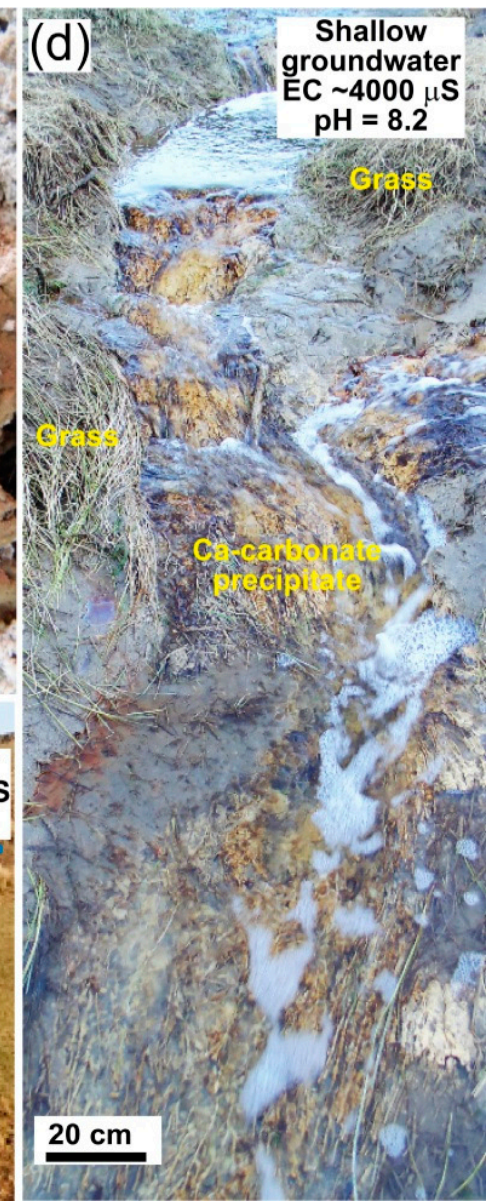

Figure 2. Outline of key features of typical water-rock interaction in Otago Schist rocks. (a) Cartoon cross section showing passage of shallow groundwater through schist, with partial evaporation of discharge springs and associated precipitates that are dominated by Ca-carbonate. (b) Outcrop view of Ca-carbonate precipitates from basement seeps. (c) Ca-carbonate precipitate from a spring emanating from a schist waste rock pile at Macraes mine (cf Figure 1a), with late-stage encrustations of epsomite. (d) Grassland stream of high-EC spring water from schist waste rock that deposited precipitates in (c), showing spontaneous Ca-carbonate precipitates on the stream bed. (e) Localised use of water similar to that in (d) for agricultural irrigation.

\subsection{Climate and Marine Aerosols}

The southern South Island generally has a temperate maritime climate (mean annual temperature $\sim 12{ }^{\circ} \mathrm{C}$ ), with warm summers, cool winters, and frequent rainfall events throughout the year. High mountains on the western side of the South Island intercept prevailing winds from the west, resulting in extreme orographic precipitation $(>10 \mathrm{~m} /$ year; Figure 1b) in those mountains. A rain shadow in the lee of those mountains affects the whole southeastern part of the island, but that rain shadow effect is most pronounced in the inland area of Central Otago where precipitation is as low as $\sim 300 \mathrm{~mm} /$ year (Figure 1b) [21]. In contrast, the eastern coast (Coastal Otago; Figure 1b) is affected by maritime winds from the east and south, and consequently receives precipitation of $\sim 1000 \mathrm{~mm} /$ year.

Atmospheric moisture from the surrounding ocean masses also contains trace quantities of marine aerosols that are dominated by salt-bearing sea spray. These salty aerosols are deposited onshore by rain, to mix with surface waters and groundwaters. The Central Otago rain shadow climate is made even more arid by frequent strong dry winds from the west, and potential evaporation exceeds $700 \mathrm{~mm} /$ year [24]. Hence, the evaporation of surface waters can, under some circumstances, leave a residue of salts with the chemical compositional proportions of sea water $[21,24]$. These residues can accumulate in the more arid parts of the rain shadow, the easternmost example of which occurs as an ephemeral 
salt lake (Figure 1b) [24]. Rainfall in Coastal Otago is too high to permit the accumulation of salts, but a geochemical signal for these salts is detectable in shallow groundwaters [24,25].

\subsection{Historic Mine Sites in This Study}

The Otago Schist hosts numerous Cretaceous orogenic gold-bearing structures that have been eroded to contribute detrital gold to form placer deposits in most of the nonmarine conglomerates and gravels that have formed since the Cretaceous. These placer deposits have been extensively mined throughout Central Otago over the past 160 years. Most historic mine sites were abandoned with no remediation, and they have since been naturally colonised by a range of native and exotic plants. Two historic ( 100 years) placer mine sites, at Springvale and Chapman Road (Figure 1b,c) host relatively rare endemic salt-tolerant or halophyte plant ecosystems, and have recently been made into scientific reserves for that reason. The general environmental controls on the halophyte habitats have been statistically quantified, showing that salinity is the principal controlling variable [26]. For the specific sites in this study, the geoecological controls on development of these rare ecosystems are linked to impermeable substrates left by the historic miners [23,27]. The sites are on the margin of an inland sedimentary basin, at $200 \mathrm{~m}$ above sea level.

Schist-derived Cretaceous nonmarine sedimentary rocks in Coastal Otago contain abundant lignite within a sequence that is dominated by quartz pebble conglomerates [28]. These rocks have been mined for lignite for $>160$ years, and the Wangaloa mine site outlined in this study (Figure 1b,d) was active from the 1950s to 1980s. The lignite is notable for its relatively high sulfur content (up to $5 \mathrm{wt} \% \mathrm{~S}$ ), especially near the tops of seams where pyrite cements both lignite and overlying quartz pebble conglomerate [29]. The Wangaloa site was subjected to substantial rehabilitation activity in the early 2000s, and has since been revegetated and managed as a recreational reserve [29]. Acid substrates have developed where residual pyrite is oxidising, with $\mathrm{pH}<2$ occurring locally $[28,29]$. This study focuses on geoecological controls on revegetation of some acidic substrates.

\section{Methods}

The sites selected for this study reflect contrasts in climate and underlying geology, and consequently have contrasts in colonising vegetation. We utilise data from a range of previous studies at these sites that were done for other purposes. These data have been augmented with new data that were specifically collected to quantify geological and geochemical thresholds between different geoecological zones that have been defined by the presence of distinctive vegetation species (Table 1). The background data for typical Otago Schist compositions, mineralogy, and water-rock geochemical interactions have been compiled from previous workers $[22,25,30]$. General methods for quantifying salinity and site-wide salinity variations at Chapman $\mathrm{Rd}$ and Springvale placer gold mines were outlined by previous workers at these sites [23,27]. General geochemical and ecological data at the Wangaloa coal mine have been previously reported with their methods $[28,29,31,32]$.

Sampling at the two gold mine Scientific Reserves was greatly restricted due to permit compliance for conservation reasons. Several areas of the site were not permissible to visit due to the occurrence of particular rare halophyte species. Consequently, only one representative detailed transect was selected at each site, in addition to the more general previous sampling [23,27]. The two additional transects cross visual boundaries of bare substrate and different vegetation types (native and adventive). The transect at Springvale was $6 \mathrm{~m}$ in length, with point samples collected every $0.5 \mathrm{~m}$ to collect 13 samples. The transect at Chapman Rd was $2 \mathrm{~m}$ in length, with point samples spaced at $0.15 \mathrm{~m}$ to obtain 13 samples. At each point, $50 \mathrm{~g}$ of substrate (depth up to $4 \mathrm{~cm}$ ) was placed into a plastic bag and transported back to the laboratory. Both gold mine transects were sampled on the same day, after several days of dry weather. The individual samples were turned into a slurry using $50 \mathrm{~mL}$ of distilled water added to an equal volume of fresh substrate, and stirred. After $1 \mathrm{~h}$, an Oakton field-portable combined electrical conductivity (EC) and $\mathrm{pH}$ meter was used to measure values for individual samples. EC is a useful measure of total 
dissolved solids in substrate pore waters at times of water saturation such as rain events. This parameter was used as a proxy for the salinity of the substrates at the gold mine sites. The EC is a useful proxy if the amount of sample is limited [17]. The ambient temperature was $\sim 20^{\circ} \mathrm{C}$ during conductivity measurements.

Table 1. Summary of key features, substrate chemistry, and plant species distributions at the mine sites and surrounding areas described in this study. EC = electrical conductivity.

\begin{tabular}{|c|c|c|c|c|}
\hline Localities & Setting & $\begin{array}{l}\text { Geoecological } \\
\text { Zones }\end{array}$ & Substrates & Principal Plant Species \\
\hline \multicolumn{5}{|c|}{$\begin{array}{l}\text { 1. Background, fully vegetated Otago Schist basement and schist-derived sediments, with circumneutral pH substrates and } \\
\text { local Ca-carbonate precipitates }\end{array}$} \\
\hline $\begin{array}{l}\text { Coastal and Central } \\
\text { Otago regions (Figure } 1 b \text { ) }\end{array}$ & $\begin{array}{l}\text { Temperate coast, and } \\
\text { inland rain shadow }\end{array}$ & $\begin{array}{l}\text { No specific } \\
\text { zonation }\end{array}$ & $\begin{array}{l}\text { Fresh and variably } \\
\text { oxidised schist }\end{array}$ & $\begin{array}{c}\text { Multiple species of native } \\
\text { and exotic grasses, herbs, } \\
\text { shrubs, forest }\end{array}$ \\
\hline \multicolumn{5}{|c|}{ 2. Differential colonisation of $\mathrm{NaCl}$ salt-rich substrates by halophytes \& salt-tolerant plants } \\
\hline \multirow{3}{*}{$\begin{array}{c}\text { Springvale and } \\
\text { Chapman Road } \\
\text { historic placer gold } \\
\text { mines (Figure 1b,c), } \\
\text { developed in Miocene } \\
\text { terrestrial sedimentary } \\
\text { rocks on schist basement }\end{array}$} & \multirow{3}{*}{$\begin{array}{l}\text { Inland basin; continental } \\
\text { climate in arid } \\
\text { rain-shadow; alkaline } \\
\text { substrates (pH 7-9) with } \\
\text { evaporitic } \\
\mathrm{NaCl} \text {-dominated salts }\end{array}$} & $\begin{array}{c}\mathrm{EC} \\
>1000 \mu \mathrm{S}\end{array}$ & $\begin{array}{c}\text { Friable bare } \\
\text { clay-rich } \\
\text { impermeable rock } \\
\text { substrates with } \\
\text { salts }\end{array}$ & Unvegetated \\
\hline & & $\begin{array}{c}\mathrm{EC} \\
>1000 \mu \mathrm{S}\end{array}$ & $\begin{array}{l}\text { Clay-rich outwash } \\
\text { pans with salts }\end{array}$ & $\begin{array}{l}\text { Lepidium kirkii; Puccinellia } \\
\text { raroflorens;Myosurus } \\
\text { minimus subsp. } \\
\text { novae-zelandiae; } \\
\text { Ceratocephala pungens; } \\
\text { Myosotis brevis (Myosotis } \\
\text { pygmaea var. minutiflora); } \\
\text { Atriplex buchananii }\end{array}$ \\
\hline & & $\begin{array}{c}\text { EC } \\
<1000 \mu S\end{array}$ & $\begin{array}{l}\text { Clay-rich outwash } \\
\text { pans }\end{array}$ & $\begin{array}{l}\text { Multiple native and exotic } \\
\text { grasses, herbs, shrubs }\end{array}$ \\
\hline
\end{tabular}

3. Differential colonisation of acid substrates by shrubs/trees: Leptospermum scoparium; Kunzea ericoides $(=\mathrm{L} \& \mathrm{~K})$; Weinmannia racemosa $(=\mathrm{W}+\mathrm{L} \& \mathrm{~K})$

\begin{tabular}{|c|c|c|c|c|}
\hline \multirow{4}{*}{$\begin{array}{c}\text { Wangaloa } \\
\text { historic coal mine } \\
\text { (Figure } 1 \mathrm{~b}, \mathrm{~d} \text { ), developed } \\
\text { in Cretaceous terrestrial } \\
\text { \& marginal marine } \\
\text { sedimentary rocks }\end{array}$} & \multirow{4}{*}{$\begin{array}{l}\text { Valley in rolling low hills; } \\
\text { cool temperate coastal } \\
\text { climate; site with acid } \\
\text { mine drainage (pH 1-7) }\end{array}$} & $\mathrm{pH}<3$ & $\begin{array}{l}\text { Variable bare mine } \\
\text { waste, with quartz } \\
\text { pebbles, pyrite \& } \\
\text { coal }\end{array}$ & Unvegetated \\
\hline & & pH 3-4 & $\begin{array}{c}\text { Variable mine waste } \\
\text { with quartz pebbles, } \\
\text { pyrite \& coal }\end{array}$ & $\begin{array}{c}\text { Leptospermum scoparium; } \\
\text { Kunzea ericoides (= L \& K } \\
\text { zone) }\end{array}$ \\
\hline & & $\mathrm{pH} 4-5$ & $\begin{array}{l}\text { Variable mine waste } \\
\text { with quartz pebbles, } \\
\text { minor coal \& pyrite }\end{array}$ & $\begin{array}{c}\text { Weinmannia racemosa; } \\
\text { Leptospermum scoparium; } \\
\text { Kunzea ericoides (= W, L \& K } \\
\text { zone) }\end{array}$ \\
\hline & & $\mathrm{pH}>5$ & $\begin{array}{c}\text { Loess (silt), quartz } \\
\text { pebbles, clays }\end{array}$ & $\begin{array}{l}\text { Weinmannia racemosa; } \\
\text { Pseudopanax colensoi; } \\
\text { Pittosporum tenufolium; } \\
\text { Pittosporum eugenoides; } \\
\text { Fuchsia excorticata; } \\
\text { Melicyctus ramiflorus; } \\
\text { Griselinia littoralis }\end{array}$ \\
\hline
\end{tabular}

At the Wangaloa coal mine site, three different locations for detailed study were selected on the basis of previous work (cited above), and quantified in order to augment these previous more general observations. The three selected transects had clear visual boundaries between bare ground and different types of vegetation establishment. The sites 
were selected on a slope on waste rock material that has distinctly acid substrates, some of which have resisted long-term (>15 years) revegetation. At each location, a tape measure transect was staked out so as to intercept visual revegetation boundaries and allow for the marking of at least 10 sampling points, depending on the scale of change over the transect length.

At each sampling point along the Wangaloa mine transects, $50 \mathrm{~g}$ of substrate was collected (depth up to $4 \mathrm{~cm}$ ) using a small trowel, and placed in a sealable plastic bag. All substrate samples were collected on the same day. Vegetation data were recorded in the field immediately following the collection of substrate samples. Samples were then returned to the laboratory and processed individually within a $2 \mathrm{~h}$ time period, to measure paste $\mathrm{pH}$ values $[29,32,33]$. Inert quartz grains were first sieved out of each substrate sample ( $2 \mathrm{~mm}$ mesh sieve), which left a smaller amount of fine grained substrate. Then $10 \mathrm{~g}$ of this fine substrate was mixed with $25 \mathrm{~mL}$ of distilled water, stirred, and left for $1 \mathrm{~h}$. An Oakton field-portable meter was then used to measure $\mathrm{pH}$ values for each individual slurry sample, with ambient air temperature of $19^{\circ} \mathrm{C}$. Since acid can continue to leach from pyrite in wet conditions, the $\mathrm{pH}$ of each slurry sample in the lab was remeasured after $24 \mathrm{~h}$, and again after 7 days, with a standardised $19^{\circ} \mathrm{C}$ ambient temperature.

\section{Background Schist-Dominated Substrates, Water and Vegetation}

In this section, we provide an overview of the geoecological features of the Otago Schist and its derivative sediments in order to quantify the natural background setting, for comparison to the distinctly different substrates in the mine sites of this study. The most prominent feature of the background schist is the relative abundance of Ca-carbonate (especially calcite) in the basement rock itself and in associated sediments (Figure 2a-d). Surface water and shallow groundwater readily dissolve calcite and redistribute the resultant alkalinity throughout the surficial environment, leading to widespread and persistent circumneutral or alkaline $\mathrm{pH}$ (Figures $2 \mathrm{~d}$ and $3 \mathrm{a}$ ). The evaporation of surface water leaves Ca-carbonate precipitates (Figure 2b), and some shallow groundwaters are sufficiently saturated with Ca-carbonate to form precipitates spontaneously (Figures 2c,d and 3a).

Pyrite within the schist is readily oxidised to yield abundant dissolved sulphate in near-surface waters, but there is more than sufficient Ca-carbonate to neutralise any acid derived from this pyrite oxidation (Figure 3a). In addition, chlorite (Fe-Mg-Al silicate) also contributes to this acid neutralisation, with release of dissolved Mg (Figure 3a) [30]. Consequently, shallow groundwaters that have contact with fresh schist debris can attain high levels of dissolved constituents, as indicated by elevated electrical conductivity (EC) levels in excess of $3000 \mu \mathrm{S}$, especially sulphate (Figures 2d,e and 3a). However, these relatively high levels of dissolved constituents do not hinder general plant growth, and most of the dissolved constituents are potential nutrients so plant growth can be enhanced with such waters (Figure 2e). The rock-derived dissolved components of these surficial waters typically dominate over those derived from marine aerosols in rain (Figure $3 a, b)$.

Schist substrates and substrates derived from schist contain sufficient macronutrients, $\mathrm{K}, \mathrm{N}$, and $\mathrm{P}$, to support plant establishment without long-term soil development. This includes rock ammonium, which is mainly hosted by primary muscovite (Figure 3c) [34]. The release of phosphorus from apatite, the main primary $\mathrm{P}$ mineral, is slow and is the principal limitation to plant growth on fresh schist substrates [34]. However, clay-altered schist typically contains more soluble P minerals, such as vivianite, and plant establishment is enhanced by this incipient alteration process [34]. The widespread schist-derived surficial loess is an especially effective substrate for vegetation establishment $[29,31]$. 

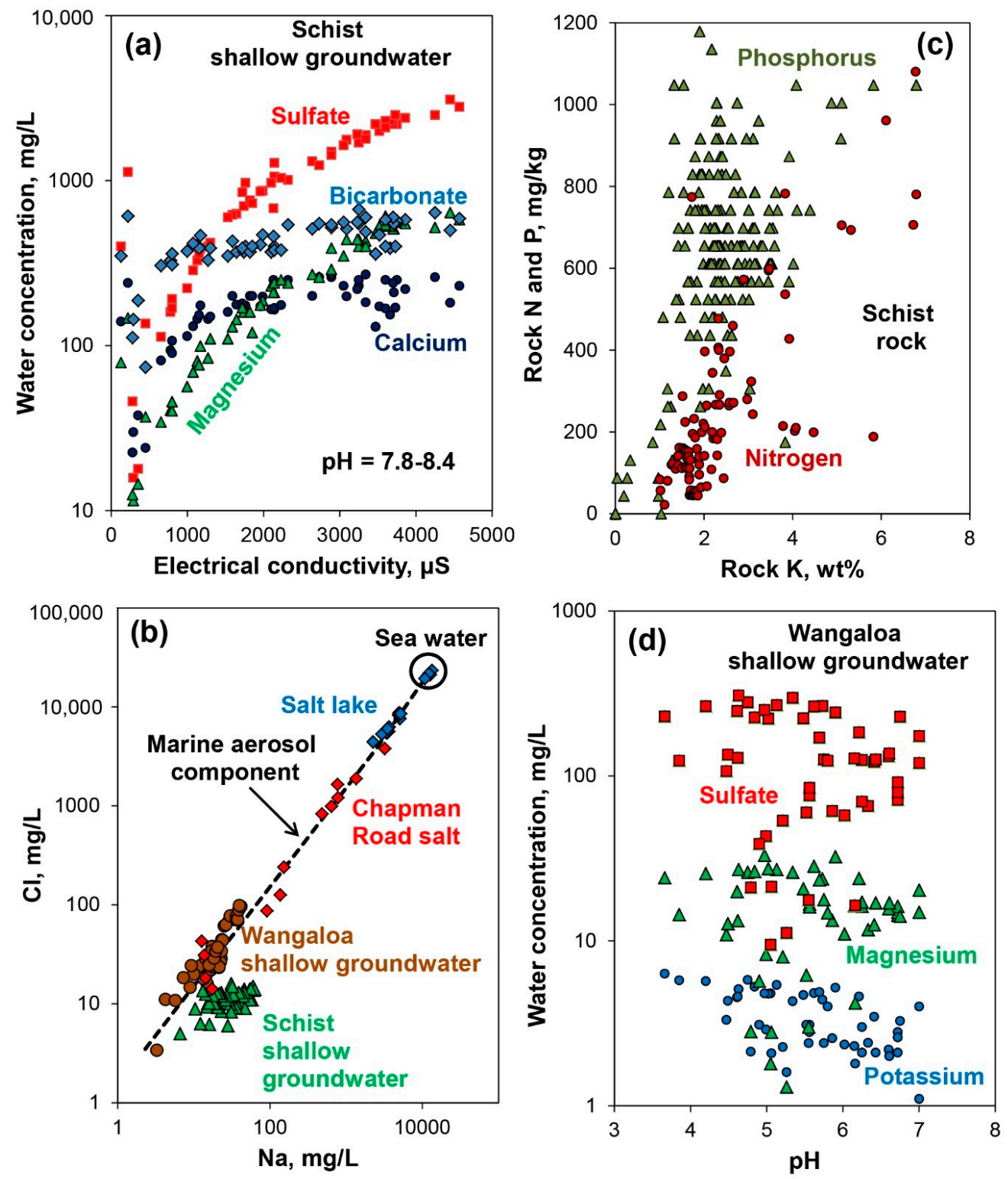

Figure 3. Contrasts between background schist-related environmental geochemistry, and the geochemistry of the historic mine sites outlined in this study. (a) Electrical conductivity and associated major ion concentrations in spring waters emanating from schist waste rock at Macraes gold mine (Figure 1a; 2b-d; Weightman et al. [30]). (b) Vegetation macronutrient contents of typical Otago Schist [34]. (c) Sodium and chloride concentrations in waters from two of the historic mine sites examined in this study, in relation to sea water and water in an inland evaporative salt lake (Figure 1a) [25]. Chapman Road data [27] indicate the dominance of $\mathrm{NaCl}$ salts, compared to the sulphate-rich schist shallow groundwater in a that yields mainly Ca-carbonate precipitates (Figure 2c,d). (d) Variations of $\mathrm{pH}$ and some shallow groundwater compositional data at Wangaloa coal mine [28].

\section{Results: Geoecological Zonation at Mine Sites}

\subsection{Salinity and Revegetation Zones at Springvale Gold Mine}

Historic mining at the Springvale site was focused on placer gold accumulations at the base of Pleistocene gravels that rest unconformably on Miocene mudstone (Figure 4a). The mudstone was derived from the underlying schist basement and consists of most of the same minerals, with clay minerals (kaolinite and smectite) instead of chlorite, although calcite is less abundant than in the schist and pyrite is relatively rare. When mining ceased, the mudstone surface ( $\sim 8 \mathrm{ha}$ ) was left exposed and abandoned. The mudstone is largely impermeable to water from rain and slope drainage, and the surface is friable as a result 
clay expansion and contraction in the upper few centimetres, so plant establishment has been severely inhibited (Figure $4 a, b$ ). In addition, the accumulation of evaporative salts from marine aerosols has made the mudstone surface variably saline, with localised and ephemeral growth of salt encrustations dominated by halite $(\mathrm{NaCl})$. Ongoing erosion of the exposed friable mudstone has led to the formation of broad clay outwash pans ( $10 \mathrm{~m}$ scale), upon which further salt accumulations have formed (Figure $4 a, b$ ).
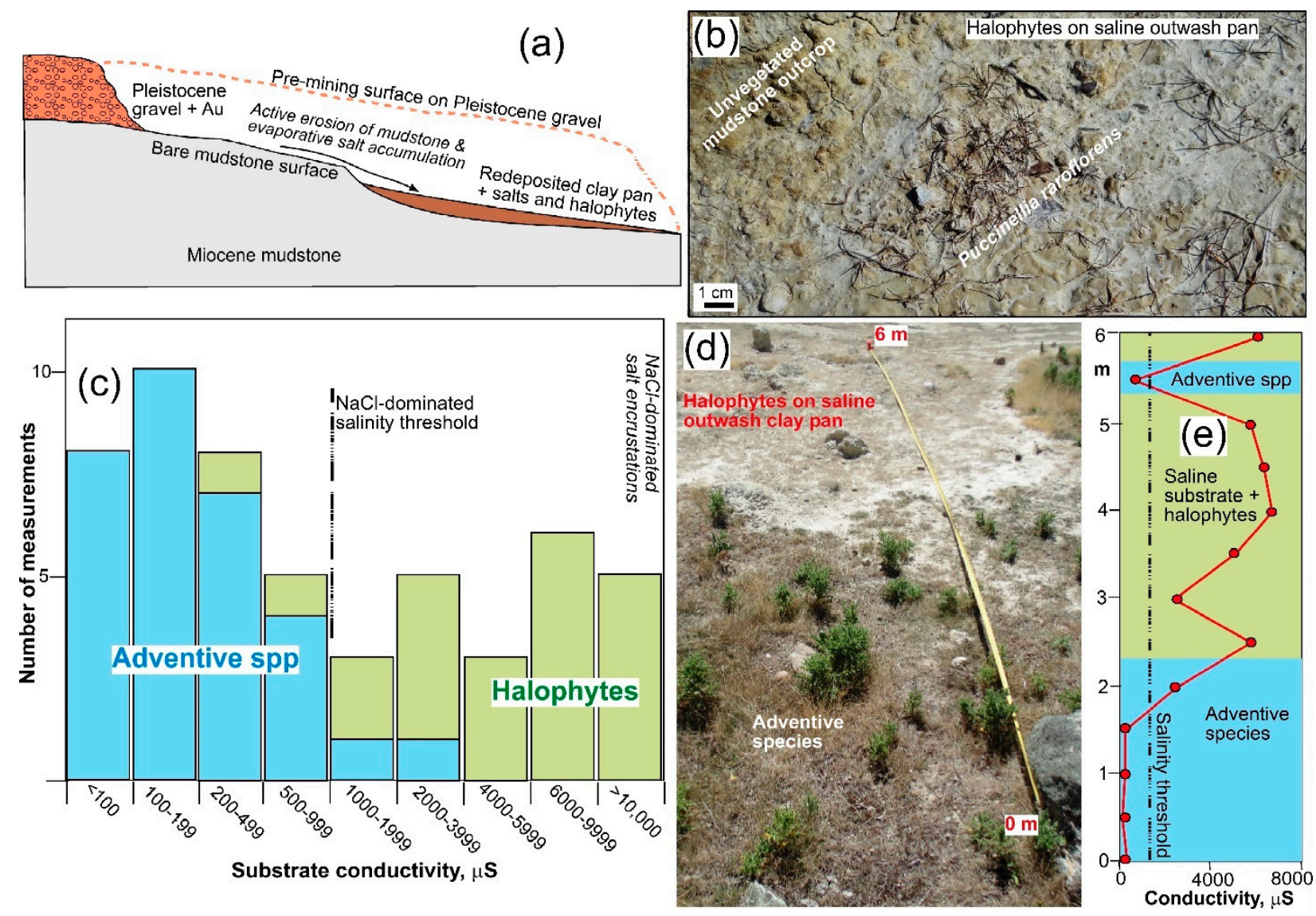

Figure 4. Springvale historic placer gold mine. (a) Sketch cross section showing the principal features at present, in relation to the premining topography. (b) Photograph of halophyte plants on an active clay outwash pan at the foot of a scarp of Miocene mudstone left by the miners. (c) Histogram of EC data from substrates across the site for halophytes and nearby adventive species [23]. (d) Photograph of the boundary between vegetation by adventive species and saline clay-rich substrate with abundant halophyte colonisation. (e) EC measurements obtained from substrate samples collected $50 \mathrm{~cm}$ apart along the taped transect in $\mathrm{d}$.

The clay outwash pans are notable for their accumulations of small (cm scale) salttolerant or halophytic plant communities (Figure $4 \mathrm{~b}$ and Table 1) that are the reason for current preservation of the site in its present form. In contrast, more distal parts of the clay pans, and parts of the site where there are remnants of Pleistocene gravel, have been naturally colonised by a wide range of adventive native and exotic species, especially exotic grasses. Hence, natural processes over the past 100 years have resulted in development of three distinct geoecological zones at the site: unvegetated friable and variably saline mudstone; outwash salt pans with halophyte communities; and general multispecies revegetation (Table 1$)$.

The boundary between the unvegetated friable mudstone and the halophyte-bearing clay outwash pans is essentially a physical feature, defined by the topographic transition from mudstone outcrop to the downstream pans (Figure $4 \mathrm{~b}$ ). In contrast, there is a salinity-based chemical boundary between the halophyte-bearing pans and surrounding 
multispecies adventive vegetation. The salinity threshold that separates the latter two geoecological zones can be quantified by substrate EC, and occurs at $\sim 1000 \mu \mathrm{S}$ as measured in a general survey across the site (Figure 4c) [23]. There is minor overlap of plant communities across this threshold (Figure 4c). Refinement of the magnitude and physical scale of the salinity threshold was obtained with a detailed transect (Figure $4 \mathrm{~d}, \mathrm{e})$. This transect generally confirmed the $\sim 1000 \mu \mathrm{S}$ threshold, but also showed that there is some overlap on the metre scale (Figure 4e), at least partly as a result of centimetre scale patchiness in salt distribution and associated vegetation cover near the boundary of these geoecological zones (Figure 4d).

\subsection{Salinity and Revegetation Zones at Chapman Rd Gold Mine}

Placer gold at the Chapman Road site had accumulated in Miocene quartz pebble conglomerate that rests on schist basement, and in overlying lithic Pleistocene gravels (Figure 5a). Historic mining removed both these sedimentary units to expose $\sim 10$ ha of the schist basement unconformity (Figure $5 a$ ). The schist basement is intensely clay-altered for up to $5 \mathrm{~m}$ immediately below the Miocene unconformity, and mining has left this clay-rich surface exposed over several hectares (Figure 5a-c). The clay-rich surface is littered with abundant quartz fragments that are remnants from schist disaggregation, with a component of remnant sedimentary quartz pebbles, forming friable slopes that have remained unvegetated (Figure $5 b$ ). These friable slopes are impermeable to rain and surface runoff, and have accumulated evaporitic salts from marine aerosols, with widespread ephemeral halite-rich encrustations (Figure $5 b, c$ ). Leachates derived from the salt encrustations have similar major ion proportions to sea water when normalised to chloride contents, with only minor deviations from the 1:1 comparison line (Figure 5c).

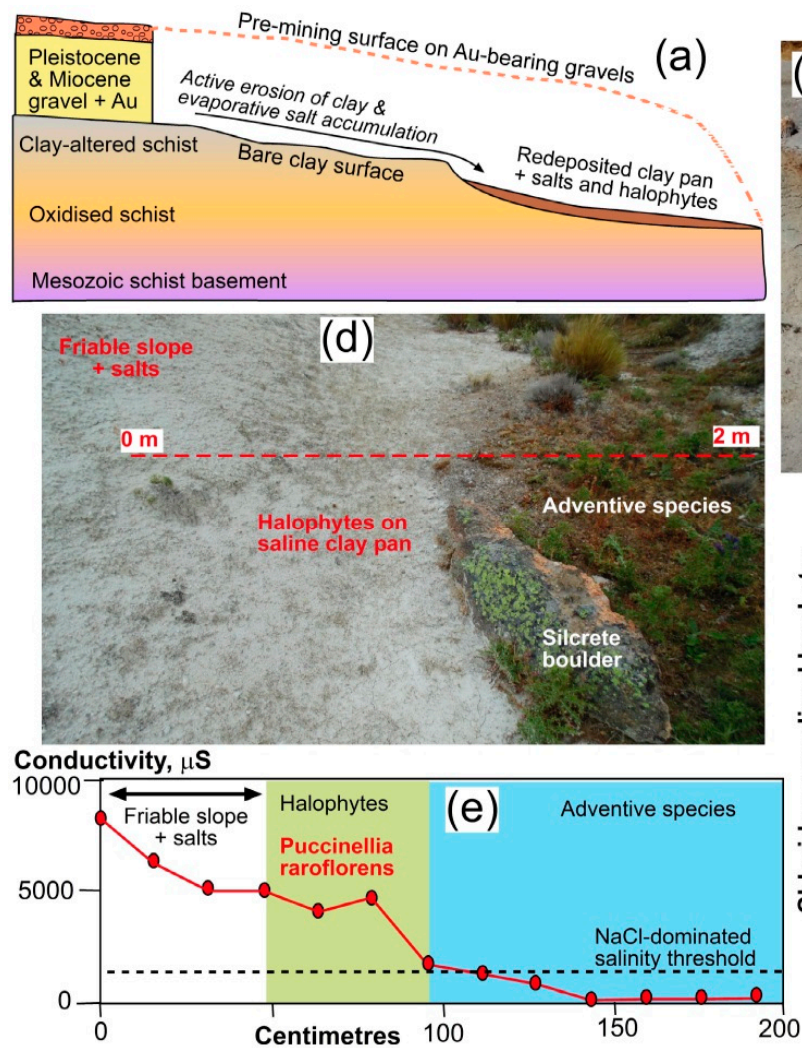

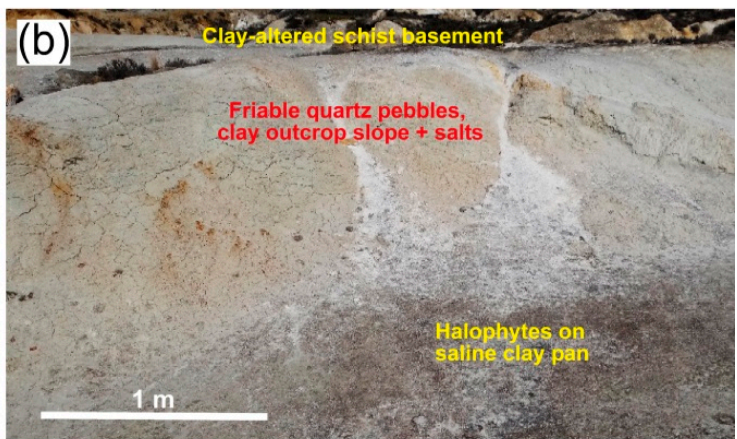

(C) Salt compositions compared to seawater

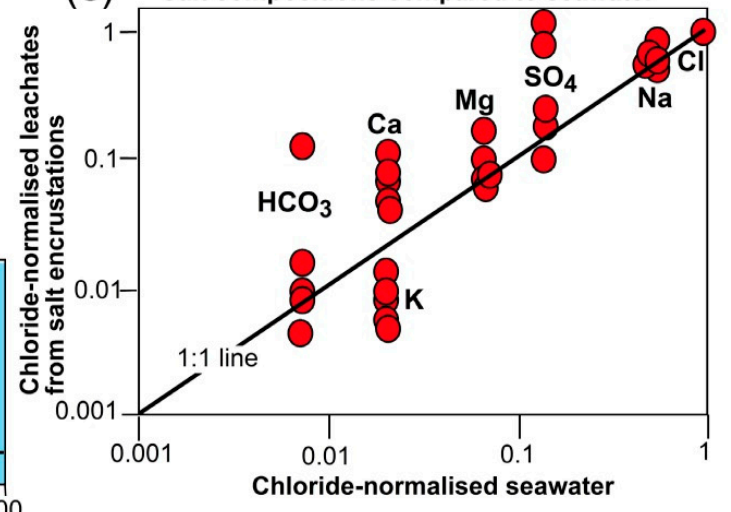

Figure 5. Chapman Road placer gold mine. (a) Sketch cross section showing the principal features at present, in relation to the premining topography. (b) Photograph of halophyte plants on a salt-encrusted active outwash pan at the foot of a scarp of clay-altered schist left by the miners. (c) Compositions of five leachate water samples from salt-rich substrates, normalised to the chloride concentrations and compared to chloride-normalised sea water [27]. (d) Photograph of the boundary between vegetation by adventive species and saline substrate with abundant halophyte colonisation. (e) EC measurements obtained from substrate samples collected along the taped transect in (d). 
Clay and quartz pebbles washed from the friable slopes have formed outwash pans on the $2-10 \mathrm{~m}$ scale, and these outwash pans now host halophyte communities (Figure $5 \mathrm{~b}, \mathrm{~d}$ and Table 1) in a similar situation to the Springvale site (above). Ephemeral salt encrustations develop locally, between rain events, on the outwash pans with the halophytes. The downstream ends of these outwash pans have been variably colonised by a range of exotic and native species (Figure $5 \mathrm{~d}, \mathrm{e}$ ). There is a salinity threshold, quantified by substrate EC of $\sim 1000 \mu \mathrm{S}$, between halophyte communities on the outwash pans and the more generally vegetated areas (Figure 5d,e), as at the Springvale site.

\subsection{Acid Substrates and Plant Colonisation at Wangaloa Coal Mine}

Coal mining at the Wangaloa site followed a gently dipping Cretaceous lignite seam down-dip in a shallow valley in the coastal Otago hills (Figures $1 \mathrm{~b}, \mathrm{~d}$ and 6a). The mine was an open cut, and up to $50 \mathrm{~m}$ of quartz pebble conglomerate was removed from above the lignite seam, as well as thin $(<5 \mathrm{~m})$ Pleistocene surficial sediments (Figure 6a). The waste rock that was removed was dumped in mined-out areas (Figure 6a), and this waste rock constitutes the principal substrate for subsequent revegetation (Figure 6b). The waste rock consists mainly of quartz pebbles, with subordinate sand, silt and clay that were formerly in the matrix and interbeds of the quartz pebble conglomerate. Some patches of waste rock also contain abundant coal fragments and pyrite-bearing material, and it is these components that contribute to localised acidification of the substrates and shallow groundwater (Figures $3 \mathrm{~d}$ and $6 \mathrm{a}-\mathrm{d}$ ). Dissolved sulphate concentrations locally exceed $300 \mathrm{mg} / \mathrm{L}$ in shallow groundwaters at the site (equivalent to EC of $1000 \mu \mathrm{S}$; Figure 3a). Shallow groundwater at the site has a minor marine aerosol component from the nearby coast, but this is overshadowed by abundant dissolved sulfate derived from pyrite oxidation (Figure 3b,d). Low levels of dissolved $\mathrm{Mg}$ and $\mathrm{K}$ in groundwaters (Figure 3d) are derived from relict schist phyllosilicates and associated clay minerals within the waste rock mass.

Peripheral unmined slopes at the site still retain their schist-derived Pleistocene cover and this substrate has been adequate for establishment of vegetation even though the topsoil had been lost. Consequently, these unmined slopes have become fully vegetated over the past $>15$ years, partly as a result of the engineered reprofiling of many surfaces and subsequent planting of native shrub species [29,32]. Since the Pleistocene surficial sediments and topsoil were first to be removed during mining, they now lie near the base of the waste rock piles over much of the site (Figure 6a), and revegetation involves direct plant establishment on the variably acid and quartz-rich substrates. During initial rehabilitation, most waste stacks were recontoured and native shrub seedlings were planted into unamended waste rock substrates, but planting death rates were high, especially on acid substrates. However, natural revegetation via native pioneer shrubs has provided an acceptable alternative cover for much of the site (Figure $6 b, e$ ). Interactions between plant species and substrate geochemical parameters have been quantified statistically in ecological studies [31,32], and from this previous work the substrate $\mathrm{pH}$ was shown to be the most significant parameter for the species considered in this study.

Natural colonisation of variably acidic substrates has resulted in some well-defined geoecological zonation, with four distinct zones forming over the past $>15$ years (Table 1) over hectare-scale areas of the site. The most acid substrates (paste $\mathrm{pH}<3$ ), which also typically have abundant quartz pebbles, remain unvegetated (e.g., Figure 6b,d). Substrates with paste $\mathrm{pH}$ between 3 and 4 host a mixture of Leptospermum scoparium and Kunzea ericoides shrubs as these have colonised from seed sources in small nearby relict stands (Figure $6 \mathrm{~b}, \mathrm{c}$ ). This geoecological zone, termed $\mathrm{L}$ and $\mathrm{K}$ zone herein (Table 1 and Figure $6 \mathrm{~b}, \mathrm{c})$, has patchy shrub establishment initially but infilling over $\sim 5-10$ years has led to complete cover in some areas. At slightly higher $\mathrm{pH}, \mathrm{L}$. scoparium and K. ericoides are joined by the shrub/tree species Weinmannia racemosa (Figure 6e,f) to form the geoecological zone termed $\mathrm{W}, \mathrm{L}$ and $\mathrm{K}$ zone herein (Table 1 ). Substrates with paste $\mathrm{pH}>5$ can host almost all the species native to the area, including any of the three species in the $\mathrm{W}, \mathrm{L}$ and $\mathrm{K}$ zone 
(Figure $6 \mathrm{c}$ and Table 1). In particular, W. racemosa persists in these higher $\mathrm{pH}$ substrates and locally forms forest trees in surrounding areas.

The acidic threshold limit for the colonisation of $W$. racemosa to form the $\mathrm{W}, \mathrm{L}$ and $\mathrm{K}$ zone is $\mathrm{pH} \sim 4$, although exact definition of this threshold is difficult because of the inherent variability of the substrates (Figure 6e,f). The threshold between unvegetated acid substrates and the $\mathrm{L}$ and $\mathrm{K}$ zone appears to be at paste $\mathrm{pH} \sim 3$ (Figure $6 \mathrm{c}$ ). More detailed definition of this important threshold was obtained from transects on a particularly acid slope that has defied full vegetation over the past 20 years (Figure 7a,b). These transects confirm the general threshold estimate of $\mathrm{pH} 3$ for $\mathrm{L}$ and $\mathrm{K}$ establishment obtained from elsewhere on the site, although there is some uncertainty in detail (Figure 7c-e). In particular, the $\mathrm{pH}$ data from these transects show the variability of paste $\mathrm{pH}$ measurements over time, which is at least partly a result of slow oxidation of pyrite in some samples (Figure 7c-e). Hence, it may not be possible to quantify this threshold exactly, although it can be observed as a sharp feature in the field at and near these transects (Figure 7f).

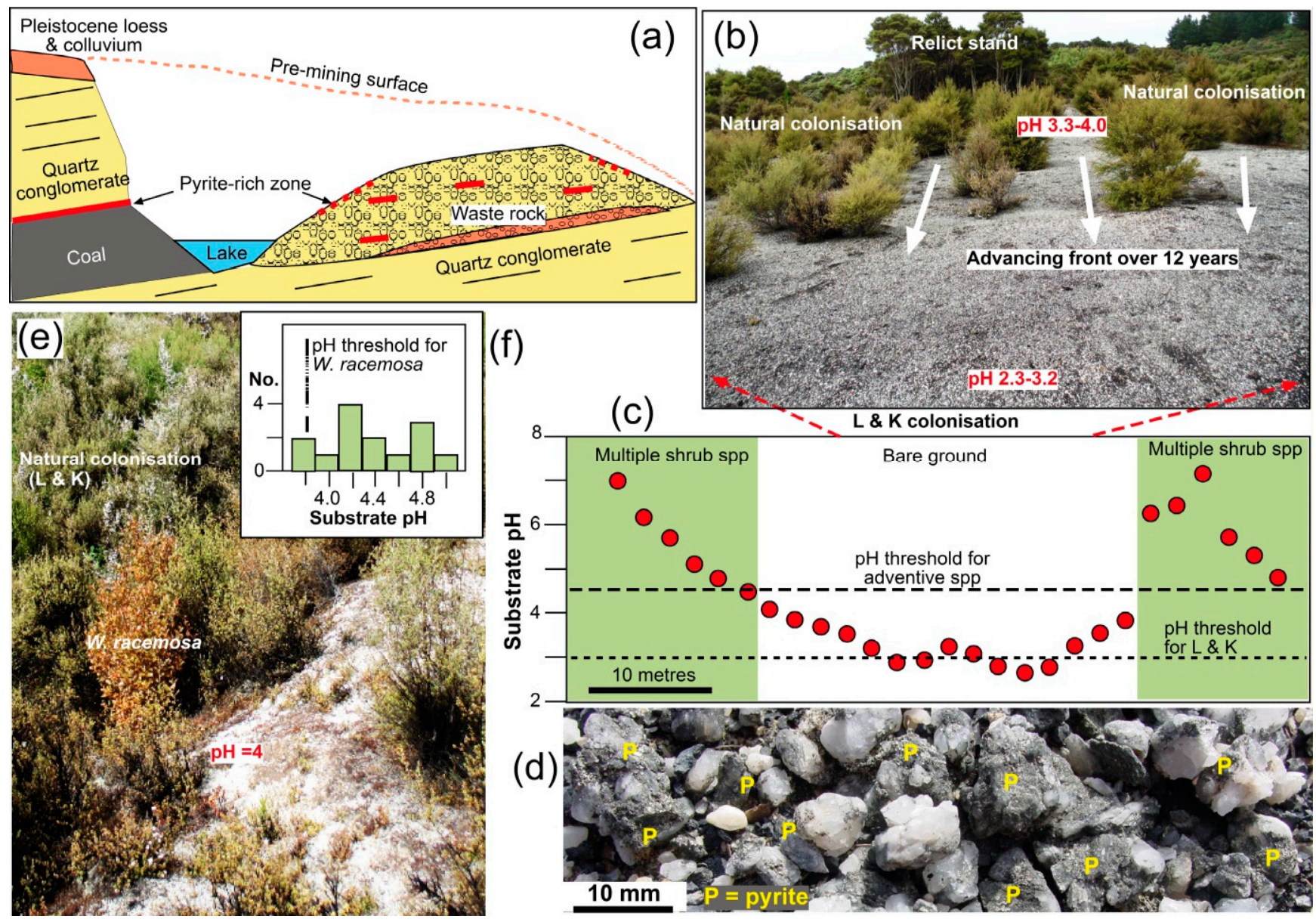

Figure 6. Wangaloa historic coal mine. (a) Sketch cross section showing the principal features at present, in relation to the premining topography. (b) Photograph (in 2015) of progressive colonisation by L. scoparium and K. ericoides (L and K) shrubs of an acid coal rich debris patch left by the miners. (c) Paste $\mathrm{pH}$ measurements obtained from substrate samples collected along a transect across the acid patch in (b). (d) Photograph of pyrite-cemented quartz pebble conglomerate (now disaggregated) from an acid patch of mine waste. (e) Photograph of the margin of an acid patch, where $\mathrm{L}$ and $\mathrm{K}$ colonisation is accompanied by Weinmannia racemosa. (f) Histogram of paste $\mathrm{pH}$ data from substrates that W. racemosa has colonised. 

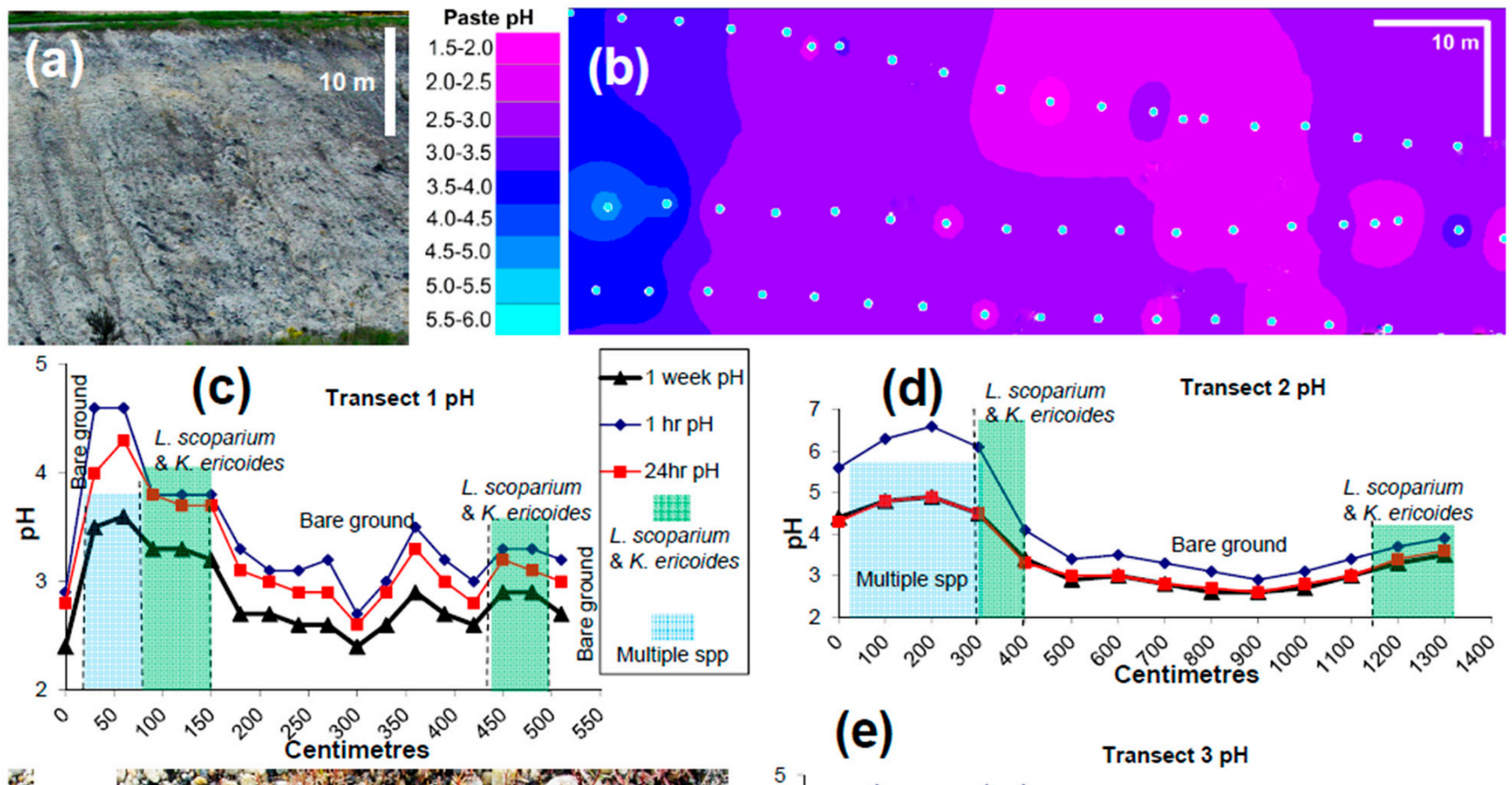

(d) L. scoparium

Transect $2 \mathrm{pH}$

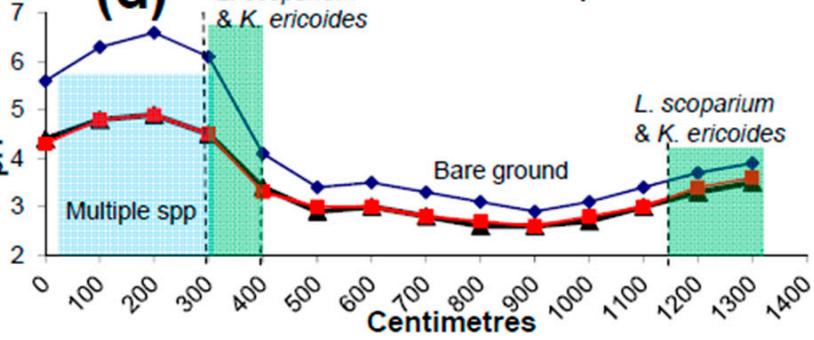

(e)
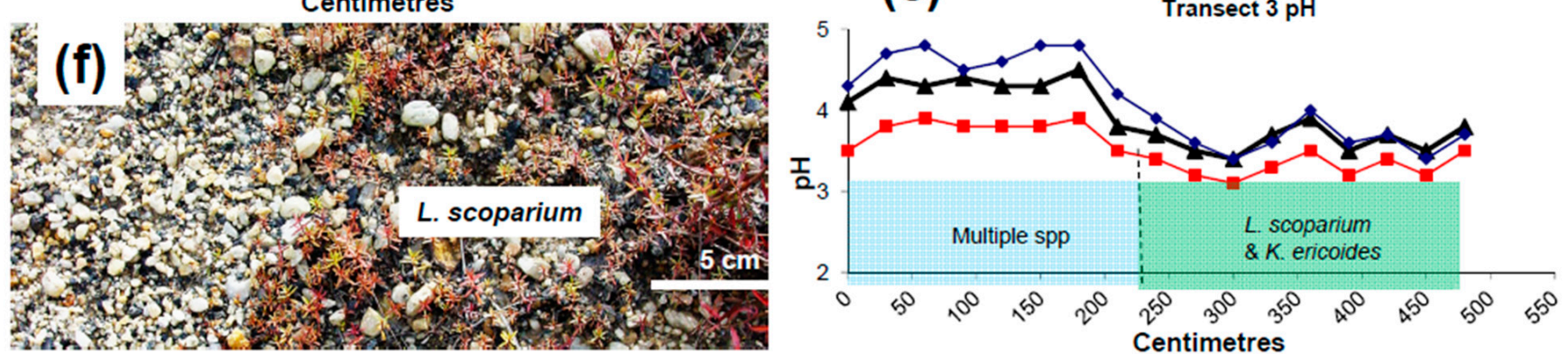

Figure 7. Acid features at Wangaloa historic coal mine. (a) Photograph of part of the most acidic waste rock slope after initial stages of rehabilitation in 2004. (b) Contoured paste $\mathrm{pH}$ data for the whole slope in a, measured in 2004. White circles are sample points. (c)-(e) Three acidity gradients showing paste $\mathrm{pH}$ values measured in the field $(1 \mathrm{~h})$ in relation to $\mathrm{pH}$ after $24 \mathrm{~h}$ and one week. Locations of L and K colonisation and more general plant establishment are indicated. (f) Photograph of L. scoparium seedlings becoming established near to the $\mathrm{pH} 3$ threshold on the acid slope in 2015. Red colouring of some seedlings is a result of acid-related stress.

\section{Discussion}

\subsection{Dynamic Thresholds}

Surface waters and shallow groundwaters associated with bare rock substrates rapidly develop distinctive localised geochemical characteristics that can control subsequent revegetation and geoecological zonation (Table 1). However, our observations on positions of salinity and $\mathrm{pH}$ thresholds have been collected over limited time scales, and changes in these positions are likely as a result of e.g., seasonal weather (Figure 8a-c) [16]. In particular, dissolution of $\mathrm{NaCl}$-dominated salts at the Springvale and Chapman Road sites is almost instantaneous during rain events unless the salts have accumulated under overhangs. Consequently, the salts are highly mobile at the sites in wet weather. Dilution of salinity in persistent wet periods, and increases in substrate salinity in dry periods are likely to cause spatial variations in the position of the salinity threshold for halophyte establishment and survival (Figure 8a,b). This may explain the occurrences of halophytes at lower EC and adventive plants at higher EC than the nominal $1000 \mu \mathrm{S}$ threshold (Figure 4c,e), as a result of a lag effect. The threshold between the halophyte geoecological zone and bare substrate is primarily physical, related to surface attrition of the underlying impermeable rocks (Figure $8 \mathrm{a}, \mathrm{b}$ ). This threshold is also affected by weather and seasons, especially heavy rain 
events that can cause sediment runoff and bury established halophytes. In addition the, accumulation of quartz pebbles, with the removal of fine sediment, can form a physically armoured surface that inhibits the establishment of plants on bare surfaces (Figure 8d).

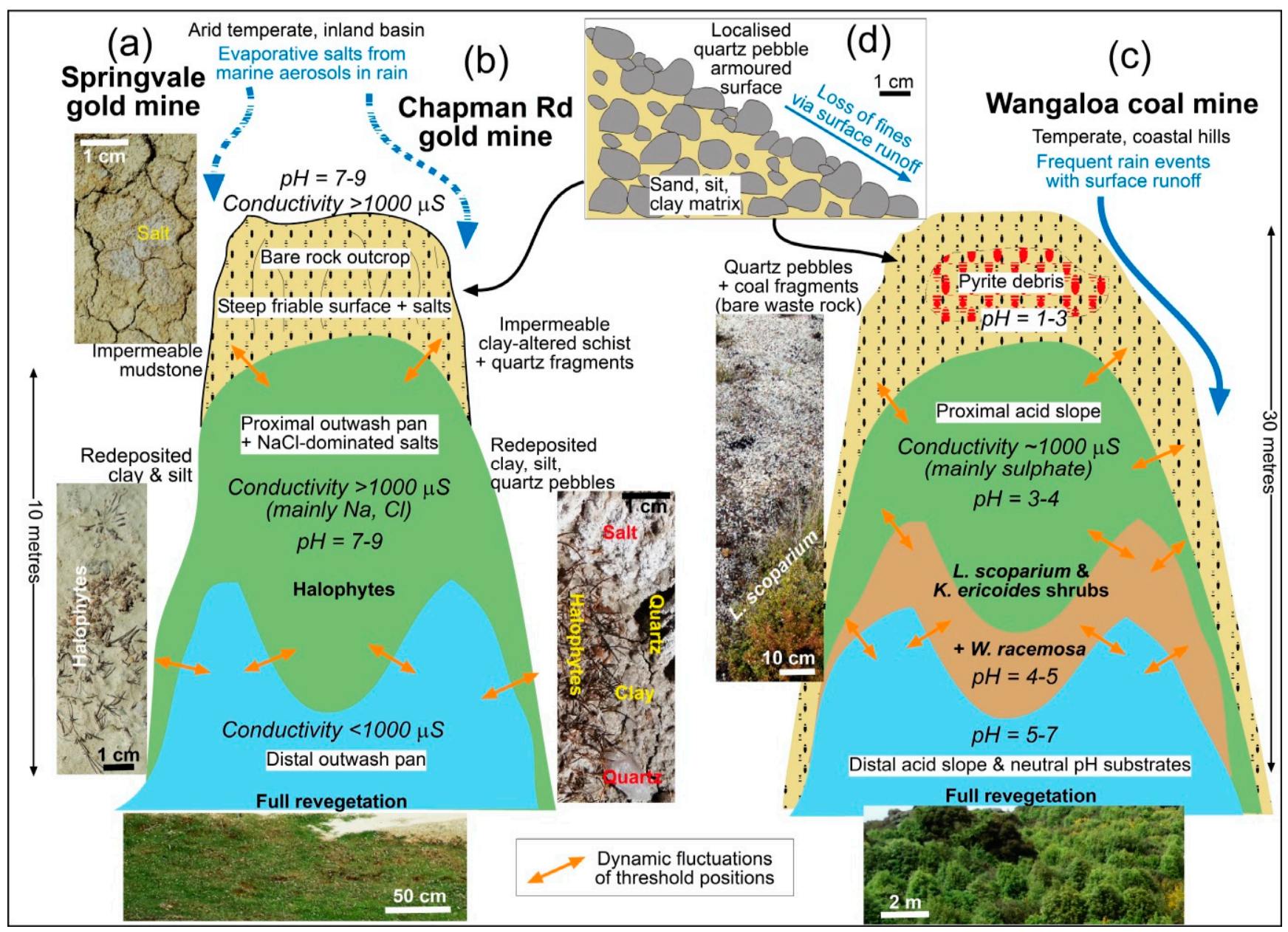

Figure 8. Cartoon summary of the principal features of geoecological zonation at the three historic mine sites in this study [35]. Threshold boundaries between the geoecological zones are dynamic on time scales of years to decades. (a) Springvale placer gold mine. (b) Chapman Road placer gold mine. (c) Wangaloa coal mine. (d) Sketch cross section through a waste rock slope rich in quartz pebbles, where pebble armouring of the slope forms a physical barrier to plant colonisation at both Chapman Road and Wangaloa mine sites.

The substrate EC threshold of $\sim 1000 \mu \mathrm{S}$ for persistent development of halophytes applies for $\mathrm{NaCl}$-dominated salinity only, and is relatively rare in the Otago environment. Typical background surface waters and substrates affected by them are dominated by Ca, $\mathrm{Mg}$, alkalinity, and sulphate from interaction with schist (Figure 3a) and high EC waters of this type do not facilitate halophyte colonisation and exclusion of other plants (Figure 2d,e). Development of the high $\mathrm{NaCl}$ salinity of halophyte-bearing substrates requires minimal geochemical interaction with schist basement or schist-derived sediments that is achieved on impermeable substrates (Figures $4 a, 5 a$ and $8 a, b)$. At the Chapman Road site, there has been some interaction between surface water and the schist substrate, resulting in enrichment in sulfate derived from pyrite, $\mathrm{Mg}$ from basement chlorite, and some extra alkalinity and Ca from basement calcite (Figure 5c). However, these interactions have had only minor effect on the overall NaCl-dominated salinity (Figure $5 \mathrm{c}$ ).

Surface water from rain events at the Wangaloa coal mine interacts with near-surface pyrite (Figures $6 \mathrm{~d}$ and $8 \mathrm{c}$ ) and can yield a flush of acidic water on a time scale of days, as inferred from our paste $\mathrm{pH}$ measurements (Figure $7 \mathrm{c}-\mathrm{e}$ ). This acid water can inhibit the 
growth of young seedlings or even kill them before they become established (Figure 7f). Conversely, long wet periods can dilute the pyrite-bearing substrate moisture and allow $\mathrm{pH}$ to rise temporarily. Hence, the positions of the lower $\mathrm{pH}$ threshold for establishment of the $\mathrm{L}$ and $\mathrm{K}$ geoecological zone $(\mathrm{pH} \sim 3)$ and the higher $\mathrm{pH}$ threshold for colonisation of $W$. racemosa (W, L and $\mathrm{K}$ zone; $\mathrm{pH}>4$ ) are dynamic and likely to fluctuate on a seasonal basis (Figure 8c). These thresholds may also be affected by development by rain water runoff of physically armoured surfaces of quartz pebbles that prevent seedling establishment (Figure 8d).

In addition to these short-term variations in substrate chemistry, there are likely to be long-term trends in the evolution of the positions of threshold positions for all geoecological zones. Acid substrate patches at the Wangaloa site have become progressively less acid over the past $>15$ years as near-surface pyrite has oxidised [29]. This has allowed the L and $\mathrm{K}$ geoecological zone to expand over areas of bare waste rock (Figures $6 \mathrm{~b}$ and $7 \mathrm{a}-\mathrm{e}$ ). The W, L and K geoecological zone has followed behind the L and K zone where the substrate $\mathrm{pH}$ has risen above $\sim 4$ (Figure $6 \mathrm{e}, \mathrm{f})$. Similar long-term trends are also occurring at the two saline sites where erosion of some bare rock surfaces has almost removed them, and the threshold between bare rock and the halophyte geoecological zone is disappearing. Where this has occurred, the catchment for salt accumulation from rain has diminished and the salinity of the outwash pans has declined, allowing the incursion of adventive species [35].

\subsection{Implications for General Mine Site Rehabilitation}

The common practice at modern mine sites of the emplacement of a uniform soil cover and uniform vegetation (e.g., Figure 1a) can be effective for land reclamation but results in a low level of biodiversity $[9,11]$. Even when natural processes eventually take over, the uniformity of the substrate ensures that similar vegetation communities persist over large areas. In this study, we have shown that this uniformity can be disrupted, and biodiversity enhanced, by allowing the natural colonisation of distinctive communities that are confined to specific geoecological zones distributed over sites on a scale of hectares. Individual geoecological zones typically occur on a scale of metres to tens of metres in width, separated by physical and/or geochemical thresholds that are centimetres to metres across and dynamic (Figure 8). In our examples, these geoecological zones developed spontaneously over time. However, armed with an understanding of the geological and geochemical basis for the development of these geoecological zones, it would also be possible to deliberately establish distinctive plant communities and the ecosystems that follow from that, on similar scales of hectares, as a portion of a larger rehabilitation programme. Some engineered intervention may be needed initially to enhance the substrate for plant colonisation, and for suitable plant species, deliberate hydroseeding could enhance the rate of plant establishment. In this study, we have focused only on salinity and $\mathrm{pH}$, but other interacting parameters such as substrate moisture, topography, and time, are likely to combine with $\mathrm{pH}$ or salinity to produce a multivariate driver [18] of geoecological zonation at mine sites where bare substrates are left exposed.

Where sufficient topsoil is available, complete and uniform cover is the normal expectation for the rehabilitation of modern mine sites (e.g., Figure 1a) [2,3,6,11]. However, topsoil is commonly in short supply, especially around historic sites that have not been rehabilitated. Without soil, the abiotic substrate status is derived from the underlying rock interface undergoing environmental evolution over time since mine excavation, as in the examples described herein. Geologically controlled revegetation in these settings is typically patchy and interspersed with bare ground, creating strong visual boundaries in plant species abundance and composition, even after $>100$ years $[8,9,11,13]$. Variations in geoecological conditions over space or time lead to variations in species assemblages and vegetation cover $[3,15,36]$. This geoecological zonation can be a desirable outcome, as in the examples described above. The geoecological thresholds that separate different plant communities can be physical and/or geochemical (e.g., Table 1 and Figure 8a-d), and may be natural or human induced [15,36-39]. Irrespective of the nature and origin of these 
thresholds, we suggest that they should be encouraged to develop wherever possible in order enhance biodiversity in rehabilitation programmes.

The gold mine sites described in this study are geochemically benign, with no issues associated with runoff water chemistry. Exposed bare rocks with abundant clays have the potential to discharge turbid water with high suspended solids, although the low topography and arid climate of our examples severely limit this issue. In fact, it is the clay outwash pans that are the most important features in establishment of geoecological zones. However, elevated suspended solids in discharge waters are likely to be the principal issue in similar situations elsewhere, until some vegetation cover can be established, either naturally or via deliberate planting, to retain the sediments on site. Excavation of sedimentation ponds to intercept and settle suspended sediments is the most common procedure for such purposes [40].

Acid rock drainage is a widespread phenomenon around mine sites around the world, and the addition of soil and vegetation cover is a widely used technique to limit acid runoff from such sites $[3,4,6]$. At the Wangaloa coal mine site described in this study, vegetation establishment directly into the varied substrates on the site overall has had a positive effect on the discharging acid load, as the geoecological zonation is dominated by multispecies native vegetation on substrates with $\mathrm{pH}>5$ [29]. Hence, it is the combination of predominant higher-pH substrates with subordinate low-pH substrates that has been effective in the establishment of the different geoecological zones that have led to enhanced biodiversity. A similar approach could be used at any mine site with acid rock drainage issues, whereby a portion of the site could be managed for the development of diverse geoecological zones, either by natural colonisation or via the deliberate planting of appropriate species $[11,39]$. Experience of engineered solutions to similar coal mine rehabilitation projects elsewhere has shown that some are not successful, and that natural colonisation is a more effective long-term process $[9,10]$.

\section{Conclusions}

The mineralogical and geochemical features of rocks exposed at the surface by mining can exert strong controls on plant colonisation of bare rock surfaces. Hence, spatial differences in physical and chemical conditions prevailing on those bare rock surfaces can lead to the zonation of ecosystems during the natural or engineered revegetation of mine sites. This geoecological zonation yields greater biodiversity than typical uniform engineered rehabilitation processes. In addition, some of the more extreme geochemical effects of mine site mineralogy can provide suitable substrates for relatively rare plants to become established, providing even greater biodiversity at a site. In this study of disparate hectare-scale sites in southern New Zealand, our observations show that the spatial arrangement of bare ground and different vegetation types is linked strongly to zonation of physical aspects of the substrates, combined with salinity or acidity. Boundaries, or thresholds, of key geochemical parameters separate these geoecological zones, and these are dynamic boundaries on scales of centimetres to metres over time scales of months to decades (Figure 8a-d).

Impermeable substrates at abandoned and unrehabilitated historic gold mines have enhanced the accumulation of evaporative salts derived from marine aerosols in rain in an inland dry climate. The salts are dominated by $\mathrm{NaCl}$, in strong contrast to regional background evaporative precipitates that are dominated by Ca-carbonates. Actively forming clay-rich pans at the gold mines receive abundant salts that limit the establishment of plants other than salt-tolerant species. Consequently, salt-tolerant ecosystems have developed naturally at these historic gold mines and these sites are sufficiently distinctive to have been preserved in formal reserves for biodiversity purposes.

Acid rock drainage from waste rocks at a historic coal mine has generated gradients in substrate $\mathrm{pH}$, and these gradients have controlled the establishment of vegetation on bare waste rock surfaces. Surface $\mathrm{pH}<3$ remains unvegetated, whereas a geoecological zone between $\mathrm{pH} 3$ and 4 has been naturally colonised by two acid-tolerant shrubs. These shrubs 
were joined by an additional tree species between $\mathrm{pH} 4$ and 5 to form another geoecological zone. At higher $\mathrm{pH}$, most regional forest species and adventive species can readily become established.

The examples of geoecological zonation described in this study involve $\mathrm{pH}$ or salinity and their controls on native New Zealand species, and consequent native ecosystems that have been controlled by the underlying physical, mineralogical and geochemical features of bare rocks at mine sites. However, the principle of encouraging enhanced biodiversity by use of distinctive features of exposed mine rocks could be applied at other mine sites in the world, especially for the very common situation of acidic substrates, provided suitable acid-tolerant plant species are available. Rather than the production of a uniform landscape with engineered rehabilitation using uniform soil cover, a portion of a site, on the scale of hectares, could be actively or passively managed for establishment of plant species that are tolerant of more extreme substrate conditions. The examples in this study show that selection of suitable tolerant species could be left to natural processes, but engineered solutions based on regional observations could also be involved.

Author Contributions: Field and laboratory work for this study was conducted by C.R., with support by D.C. The manuscript was written by D.C. with input by C.R. All authors have read and agreed to the published version of the manuscript.

Funding: This research was funded by University of Otago.

Data Availability Statement: Data for this study are presented in the paper and in cited references.

Acknowledgments: Plant identifications and information provided by Craig Wilson from the Department of Conservation were invaluable in the understanding of the inland rare ecosystems described here. We are grateful for the permission to sample and visit the protected sites, and for additional information provided by John Barkla in the Department of Conservation, and by David Lyttle. Ongoing access to the closed coal mine from Solid Energy N.Z. Ltd., City Forests, and the local community has been much appreciated.

Conflicts of Interest: The authors declare no conflict of interest. The funding body had no role in the design of the study; in the collection, analyses, or interpretation of data; in the writing of the manuscript, or in the decision to publish the results.

\section{References}

1. Wong, M.H. Ecological restoration of mine degraded soils with emphasis on metal contaminated soils. Chemosphere 2003, 50, 775-780. [CrossRef]

2. Johnson, D.B.; Hallberg, K.B. Acid mine drainage remediation options: A review. Sci. Total Environ. 2005, 338, 3-14. [CrossRef] [PubMed]

3. Anawar, H.M. Sustainable rehabilitation of mining waste and acid mine drainage using geochemistry, mine type, mineralogy, texture, ore extraction and climate knowledge. J. Environ. Manag. 2015, 158, 111-121. [CrossRef]

4. Hudson-Edwards, K.; Dold, B. Mine waste characterization, management and remediation. Minerals 2015, 5, 82-85. [CrossRef]

5. Parbhakar-Fox, A.; Fox, N.; Jackson, L.; Cornelius, R. Forecasting geoenvironmental risks: Integrated applications of mineralogical and chemical data. Minerals 2018, 8, 541. [CrossRef]

6. Vriens, B.; Plante, B.; Seigneur, N.; Jamieson, H. Mine waste rock: Insights for sustainable hydrogeochemical management. Minerals 2020, 10, 728. [CrossRef]

7. Macdonald, S.E.; Landhaüsser, S.M.; Skousen, J.; Franklin, J.; Frouz, J.; Hall, S.; Jacobs, D.F.; Quideau, S. Forest restoration following surface mining disturbance: Challenges and solutions. New For. 2015, 46, 703-732. [CrossRef]

8. Bradshaw, A. The use of natural processes in reclamation-Advantages and difficulties. Landsc. Urban Plan. 2000, 51, 89-100. [CrossRef]

9. Prach, K.; Hobbs, R.J. Spontaneous succession versus technical reclamation in the restoration of disturbed sites. Restor. Ecol. 2008, 16, 363-366. [CrossRef]

10. Haigh, M. Building a cradle for nature: A paradigm for environmental reconstruction. In Bio-Geotechnologies for Mine Site Rehabilitation; Prasad, M.N.V., Favas, P., Maiti, S.K., Eds.; Elsevier: Amsterdam, The Netherlands, 2018; pp. 593-615. ISBN 978-0-12-812986-9.

11. Tropek, R.; Kadlec, T.; Hejda, M.; Kocarek, P.; Skuhrovec, J.; Malenovsky, I.; Vodka, S.; Spitzer, L.; Banar, P.; Konvicka, M. Technical reclamations are wasting the conservation potential of post-mining sites. A case study of black coal spoil dumps. Ecol. Eng. 2012, 43, 13-18. [CrossRef] 
12. Freitas, H.; Prasad, M.N.V.; Pratas, J. Plant community tolerant to trace elements growing on the degraded soils of São Domingos mine in the south east of Portugal: Environmental implications. Environ. Int. 2004, 30, 65-72. [CrossRef]

13. Valente, T.; Gomes, P.; Pamplona, J.; Luisa de la Torre, M. Natural stabilization of mine waste dumps-Evolution of the vegetation cover in distinctive geochemical and mineralogical environments. J. Geochem. Explor. 2012, 123, 152-161. [CrossRef]

14. Hodacova, D.; Prach, K. Spoil heaps from brown coal mining: Technical reclamation versus spontaneous revegetation. Restor. Ecol. 2003, 11, 385-391. [CrossRef]

15. Huggett, A.J. The concept and utility of 'ecological thresholds' in biodiversity conservation. Biol. Conserv. 2005, 124, 301-310. [CrossRef]

16. Montemayor, M.B.; Price, J.; Rochefort, L. The importance of $\mathrm{pH}$ and sand substrate in the revegetation of saline non-waterlogged peat fields. J. Environ. Manag. 2015, 163, 87-97. [CrossRef] [PubMed]

17. Bennett, S.J.; Barrett-Lennard, E.G.; Colmer, T.D. Salinity and water logging as constraint to saltland pasture production: A review. Agric. Ecosyst. Environ. 2009, 129, 349-360. [CrossRef]

18. Blecker, S.W.; Stilling, L.L.; Amacher, M.C.; Ippolito, J.A.; DeCrappeo, N.M. Development of vegetation based soil quality indices for mineralized terrane in arid and semi-arid regions. Ecol. Indic. 2012, 20, 65-74. [CrossRef]

19. NIWA. The New Zealand National Climate Database. 2012. Available online: http:/ / cliflo.niwa.co.nz/ (accessed on 4 February 2014).

20. Douglas, B.J. Lignite Resources of Central Otago; University of Auckland: Auckland, New Zealand, 1986; 368p.

21. Craw, D.; Druzbicka, J.; Rufaut, C.; Waters, J. Geological controls on paleo-environmental change in a tectonic rain shadow, southern New Zealand. Palaeogeog. Palaeoclim. Palaeoecol. 2013, 370, 103-116. [CrossRef]

22. Chamberlain, C.P.; Poage, M.A.; Craw, D.; Reynolds, R.C. Topographic development of the Southern Alps recorded by the isotopic composition of authigenic clay minerals, South Island, New Zealand. Chem. Geol. 1999, 155, 279-294. [CrossRef]

23. Law, S.; Rufaut, C.; Lilly, K.; Craw, D. Geology, evaporative salt accumulation and geoecology at Springvale historic gold mine, Central Otago, New Zealand. N. Z. J. Geol. Geophys. 2016, 59, 382-395. [CrossRef]

24. Craw, D.; Beckett, S. Water and sediment chemistry of Sutton Salt Lake, east Otago, New Zealand. N. Z. J. Mar. Freshw. Res. 2004, 38, 315-328. [CrossRef]

25. Craw, D.; Kerr, G. Geochemistry and mineralogy of contrasting supergene gold alteration zones, southern New Zealand. Appl. Geochem. 2017, 85, 19-34. [CrossRef]

26. Rogers, G.M.; Hewitt, A.; Wilson, J.B. Ecosystem-based conservation strategy for Central Otago's saline patches. Sci. Conserv. 2000, 166, 39.

27. Druzbicka, J.; Rufaut, C.; Craw, D. Evaporative mine water controls on natural revegetation of placer gold mines, southern New Zealand. Mine Water Environ. 2015, 34, 375-387. [CrossRef]

28. Begbie, M.; Craw, D.; Rufaut, C.; Martin, C. Temporal and spatial variability of acid rock drainage in a rehabilitated coal mine, Wangaloa, South Otago, New Zealand. N. Z. J. Geol. Geophys. 2007, 50, 227-238. [CrossRef]

29. Rufaut, C.; Craw, D.; Foley, A. Mitigation of acid mine drainage via a revegetation programme in a closed coal mine in southern New Zealand. Mine Water Environ. 2015, 34, 375-387. [CrossRef]

30. Weightman, E.; Craw, D.; Rufaut, C.; Kerr, G.; Scott, J. Chemical evolution and evaporation of shallow groundwaters discharging from a gold mine, southern New Zealand. Appl. Geochem. 2020, 122, 104766. [CrossRef]

31. Rufaut, C.; Hammit, S.; Craw, D.; Clearwater, S.G. Plant and invertebrate assemblages on waste rock at Wangaloa coal mine, Otago, New Zealand. N. Z. J. Ecol. 2006, 30, 311-319.

32. Todd, A.; Rufaut, C.; Craw, D.; Begbie, M. Indigenous plant species establishment during rehabilitation of an opencast coal mine, south-east Otago, New Zealand. N. Z. J. For. Sci. 2009, 39, 81-98.

33. Sobek, A.A.; Schuller, W.A.; Freeman, J.; Smith, R.M. Field and Laboratory Methods Applicable to Overburdens and Minesoils; EPA-600/2-78-054; Environ Protection Agency: Washington, DC, USA, 1978.

34. Craw, D.; Rufaut, C. Geochemical and mineralogical controls on mine tailings rehabilitation and vegetation, Otago Schist, New Zealand. N. Z. J. Geol. Geophys. 2017, 60, 176-187. [CrossRef]

35. Rufaut, C.G.; Craw, D.; Law, S.; Druzbicka, J. Conservation of saline patches in Central Otago needs better recognition of physical processes to secure future habitats. N. Z. J. Bot. 2018, 56, 115-126. [CrossRef]

36. Lindenmayer, D.B.; Luck, G. Synthesis: Thresholds in conservation and management. Biol. Conserv. 2005, 124, 351-354. [CrossRef]

37. Hobbs, R.J.; Norton, D.A. Towards a conceptual framework for restoration ecology. Restor. Ecol. 1996, 4, 93-110. [CrossRef]

38. Scheffer, M.; Carpenter, S.; Foley, J.A.; Folke, C.; Walker, B. Catastrophic shifts in ecosystems. Nature 2001, 413, 591-596. [CrossRef] [PubMed]

39. Novak, J.; Prach, K. Artificial sowing of endangered dry grassland species into disused basalt quarries. Flora 2010, 205, 179-183. [CrossRef]

40. Younger, P.; Banwart, S.; Hedin, R. Mine Water: Hydrology, Pollution, Remediation; Springer: Berlin, Germany, 2002; 442p. 